\title{
Management of Secretory Diarrhea
}

\author{
Claudia Velázquez¹, Fernando Calzada², \\ Mirandeli Bautista ${ }^{1}$ and Juan A. Gayosso ${ }^{1}$ \\ 1 Universidad Autónoma del Estado de Hidalgo \\ ${ }^{2}$ Edificio CORCE $2^{\circ}$ piso, CMN S XXI, IMSS \\ México
}

\section{Introduction}

"Diarrhea is the passage of 3 or more loose or liquid stool per day, or more frequently than is normal for the individual. It is usually a symptom of gastrointestinal infection, which can be caused by a variety of bacterial, viral and parasitic organisms, infection is spread through contaminated food or drinking-water, or from person to person as a result of poor hygiene" (WHO). Diarrheal diseases affect all races, sexes, ages and geographic areas, has high impact on mortality and morbidity worldwide, an estimated 2-4 billion episodes of infectious diarrhea occurred each year and are especially prevalent in infants (Hodges and Gill 2010; Farthing 2002). In 2005, 1.8 million people died worldwide from diarrheal diseases (WHO, 2007). In México, in the past 6 years, the gastrointestinal infection has been a serious health problem and was the second cause of morbidity among all age groups (SS, 2008).

\section{Pathophysiology classification of diarrhea}

- Osmotic; is caused by poorly absorbable solutes (eg. sorbitol, magnesium salts) remaining in the gastrointestinal lumen retain water and electrolytes resulting in reduced water reabsorption

- $\quad$ Altered Motility; caused slowing of the motor function of the small intestine as with narcotic use, scleroderma, diabetic autonomic neuropathy and amyloidosis

- Exudative; the intestinal epithelium's barrier function is compromised by loss of epithelial cells or disruption of tight junctions (eg. E. coli, Salmonella, Shigella, Yersinia, Campilobacter, Mycobacteryum tuberculosis, Clostridium difficile y Entamoeba histolytica), inflammatory disease process as in ulcerative colitis and Crohn's disease

- Secretory; is caused by an increase in water and electrolytes (Chloride or bicarbonate) movements to the intestinal lumen, the final effect is the increase of secretion and decrease of absorption of net sodium and water (Navaneethan and Giannella, 2010).

\subsection{Secretory diarrhea}

Secretory diarrhea occurs when the balance between absorption and secretion in the small intestine is disturbed by excessive secretion caused by bacterial enterotoxins, is a net movement from mucous intestinal to lumen, the volume exceed $10 \mathrm{~mL} / \mathrm{Kg} /$ day, and the osmolarity is similar with plasma. It is the leading cause of death in infants in developing 
countries and currently accounts for an estimated of three million deaths each year among under 5 years old children (Casburne-Jones and Farthing, 2004; Filbin 2004). Most causes of secretory diarrhea alter the second messenger system through alteration in cAMP, cGMP or intracellular calcium regulated ion transport pathways, alterations in these mediators cause CFTR-mediated $\mathrm{Cl}^{-}$secretion an inhibition of small intestinal-coupled $\mathrm{Na}^{+}-\mathrm{Cl}^{-}$transport (Navaneethan and Giannella, 2010)

\subsubsection{Secretory diarrhea noninfectious}

Some of these include

- Tumors (pancreatic islet, which secrete vasoactive intestinal peptide (VIP), carcinoid which elaborate serotonin, bradykinin, substance $\mathrm{P}$ and prostaglandins, medullary carcinoma of thyroid-secreting calcitonin)

- Neurotransmitters are also potent secretory stimuli, such as histamine in systemic mastocytosis and inflammatory cytokines

- Malabsorbed bile salts and fatty acids (hydroxyl fatty acids also stimulate colonic secretion)

- The congenital absence or alterations in the numerous transporters that maintain the constant flux of the ions and water

- Rare congenital syndromes: congenital chloridorrhea, there is a defect in brush border $\mathrm{Cl}^{-} / \mathrm{HCO}_{3}{ }^{-}$exchange in the ileum and the colon and hence impaired absorption of chloride, congenital sodium diarrhea results from a congenital defect in $\mathrm{Na}^{+}$-bile acid absorption in the colon (Navaneethan and Giannella, 2010; Filbin 2004)

\subsubsection{Secretory diarrhea caused by pathogens}

Microbial causes include rotavirus, norovirus, Cryptosporidium, its affects the absorptive villi inhibiting sodium absorption. Enterotoxigenic E. coli (ETEC), $V$. cholera elaborate enterotoxins that stimulate intestinal chloride secretion along with impaired sodium absorption, Giardia lambia adhere to the mucosa disrupting the absorptive/secretary process of enterocyte producing active secretion (Navaneethan and Giannella, 2010)

\subsubsection{Enterotoxigenic bacteria}

- Vibrio cholerae

- Enterotoxigenic Escherichia coli

- Clostridium perfringes

- C. botulinum

- Campylobacter jejuni

- Klepsiella pneumoniae

- Aeromonas hydrophila

- Yersinia enterocolitic

\subsubsection{Enteroinvasive bacteria}

- Enteroinvasive Escherichia coli

- Salmonella typhi

- S. enteritidis

- $\quad$ Shigella spp 
- Campylobacter jejuni

- Plesiomonas shigeloids

- Yersinia enterocolitic

- Vibrio parahaemolyticus

\subsubsection{Viruses}

- Group A rotaviruses, G1 and G serotypes

- Norovirus (old term of Nolwalk virus)

- Parvoviruses (Hawai, Colorado, Ditchilling

- Enteric adenoviruses 40 and 41

- Coronaviruses

- Calciviruses

- Astroviruses

\subsubsection{Parasites}

- Gardia lamblia

- Entamoeba histolityca

- Cryptosporidium paroum

- Isospore belli

- $\quad$ Sarcosystis $s p$

- Cyclospore cayetanensis

- Blastocystis hominis

- Microsporidie

\subsection{Diarrhea caused by enterotoxins}

A number of several bacteria cause diarrhea by the production of potent enterotoxins, such as enterotoxigenic Escherichia coli, Salmonella typhi, S. typhimurium, clostridium difficile, C. freundii, Aeromonas hydrophila, Yersinia enterocolic, Camphylobacter jejuni and Vibrio cholera. Enterotoxins have their effect on the enterocyte functions by stimulating the secretion of transepitelial electrolytes, increasing the osmotic flux of water and ions to the intestinal lumen, specifically, heat-labile (LT) and heat stable (ST) enterotoxins from E. coli, $\mathrm{V}$. cholera and C. jejuni increase net fluid secretion by affecting the enzymes adenylate cyclase or guanilate cyclase by activation of the cAMP (cyclic 3',5'-adenosine monophosphate) in the mucosal epithelium which induces an increase of intestinal secretion and causes diarrhea.(Casburn-Jones and Farthing 2004, Amstrong and Cohen, 1999).

\subsubsection{Vibrio cholerae enterotoxin}

Vibrio cholerae enterotoxin is an oligomeric protein which is composed by two subunits, A subunit of $27.2 \mathrm{KDa}$ composed as A1 and A2 subunits, and B subunit composed by five subunits B of $11.6 \mathrm{KDa}$ each one, $\mathrm{AB}_{5}$ complex Fig 1. (Sixma, 1991)

\subsubsection{Vibrio cholerae enterotoxin mechanism}

Mechanisms proposed to secretory diarrhea caused by $V$. cholera enterotoxin involves the union of subunits B to the oligosaccharide portion of the receptor GM1, present in the apical surface of enterocytes, this union lend the entrance of A subunit of toxin to the enterocyte for acidic endosomes, which pick up the golgi apparatus and endoplasmic reticulum, 

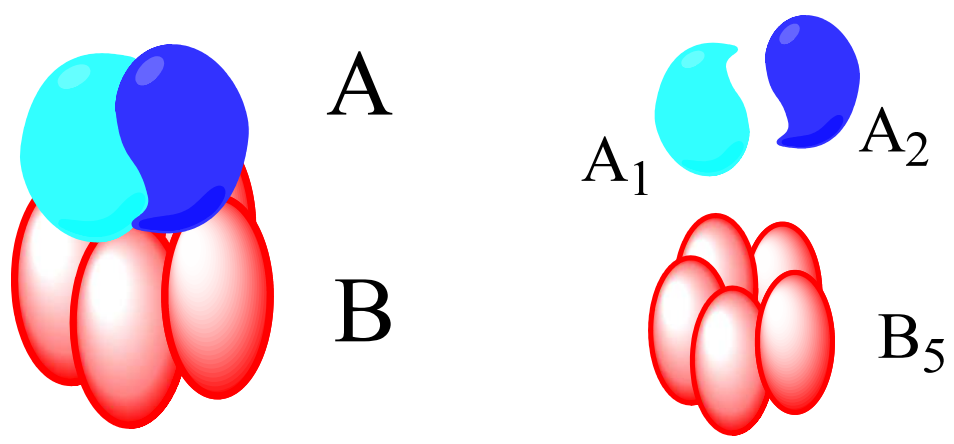

Fig. 1. Vibrio cholerae enterotoxin $\mathrm{AB}_{5}$ complex

inside of enterocyte disulphure bond between A1-A2 is dissolved by protein disulfide isomerase, it causes release of $\mathrm{A} 1$ which is capable of binding NAD and catalyzing the NADP-ribosylation of $\mathrm{G}_{\mathrm{s} \alpha}$, a GTP-binding regulatory protein associated with adenylate cyclase. A1 subunit stimulates increasing of 1000 times production of cAMP second messenger, cAMP active protein cinase A, which phosphorile and activate transmembranal chloride channels of the enterocytes located on intestinal crypts, it causes massive secretion of water and electrolytes to intestinal lumen, in villus cell there is a decrease of absorption of $\mathrm{Na}^{+}$and $\mathrm{Cl}^{-}$ions (Kopic 2010). Fig 2. shows the proposed mechanism to the action of Vibrio Cholerae enterotoxin. At 5 to 10 minutes to the exposure of V. cholera toxin cause intestinal hypersecretion of water and electrolytes for several hours (Thiagarajah, 2005; Spangler, 1992). The symptoms are manifested as severe cramp and the copious "rice water" diarrhea characteristic of the disease.

\subsection{Dehydration}

During diarrhea there is an increased loss of water and electrolytes (sodium, chloride, potassium and bicarbonate) in the liquid stool; dehydration occurs when these losses are not replaced adequately and a deficit of water and electrolytes develops. The degree of dehydration is graded according to signs and symptoms that reflect the amount of fluid lost:

- In the early stages of dehydration, there are no signs or symptoms

- As dehydration increases, signs and symptoms develop. Initially these include: thirst, restless or irritable behavior, decreased skin turgor, sunken eyes, and sunken fontanel (in infants).

- In severe dehydration, these effects become more pronounced and the patient may develop evidence of hypovolemic shock, including: diminished consciousness, lack of urine output, cool moist extremities, a rapid feeble pulse, low or undetectable blood pressure, and peripheral cyanosis.

- $\quad$ Death follows soon if rehydration is not started quickly (WHO, 2005).

\subsection{Secretory diarrhea treatment}

\subsubsection{Oral rehydration}

To control diarrhea disease, a sufficient hydration of the patient should be procure and provide the necessary ions to maintain electrolyte balance, the treatment of choice is oral 




Fig. 2. Cholera toxin mechanism proposed by Velázquez et al., $A_{1,2} B_{5}$ (subunits), GM1 (ganglioside receptor), Gs $\alpha$ (G protein), cAMP (cyclic AMP), CFTR (cystic fibrosis transmembrane conductance regulator).

rehydration solution (ORS), it has reduced the levels of mortality in children and elderly by dehydration, but not morbidity (Turvill et al., 2000), the treatment is based by active absorption of glucose by smooth intestine, during the intestinal infection lend to the cotransport of $\mathrm{Na}^{+}$ions and water absorption. WHO and UNICEF guidelines recommend their use, is important to notice that ORS, is useful to treat dehydration caused by diarrhea, but it not decrease the amount and duration at the same. Depends of severity of diarrhea, in some cases ORS is not enough and antibiotic, spasmolytic, and antiprotozoal drugs should be used. WHO recommended use of secure and effective drugs to the pediatrics (Marion et al., 2010). 


\subsubsection{Drugs used to treat secretory diarrhea}

To treat the secretory diarrhea there are some drugs which reduce the intestinal movement such as codeine (1), loperamide (2), diphenoxylate (3), lidamidine (4), bismuth subsalicylate (5), racecadotril (6) and clonidine (7) Table 1.; which are capable to stimulate absorption direct and reduce secretion of water and electrolytes in gastrointestinal tract, to decrease propulsion, contact time of intestinal content with mucosal surface increase, it favors the absorption. They act not premised release of prostaglandins too (Marion et al., 2010; Martindale 2009).

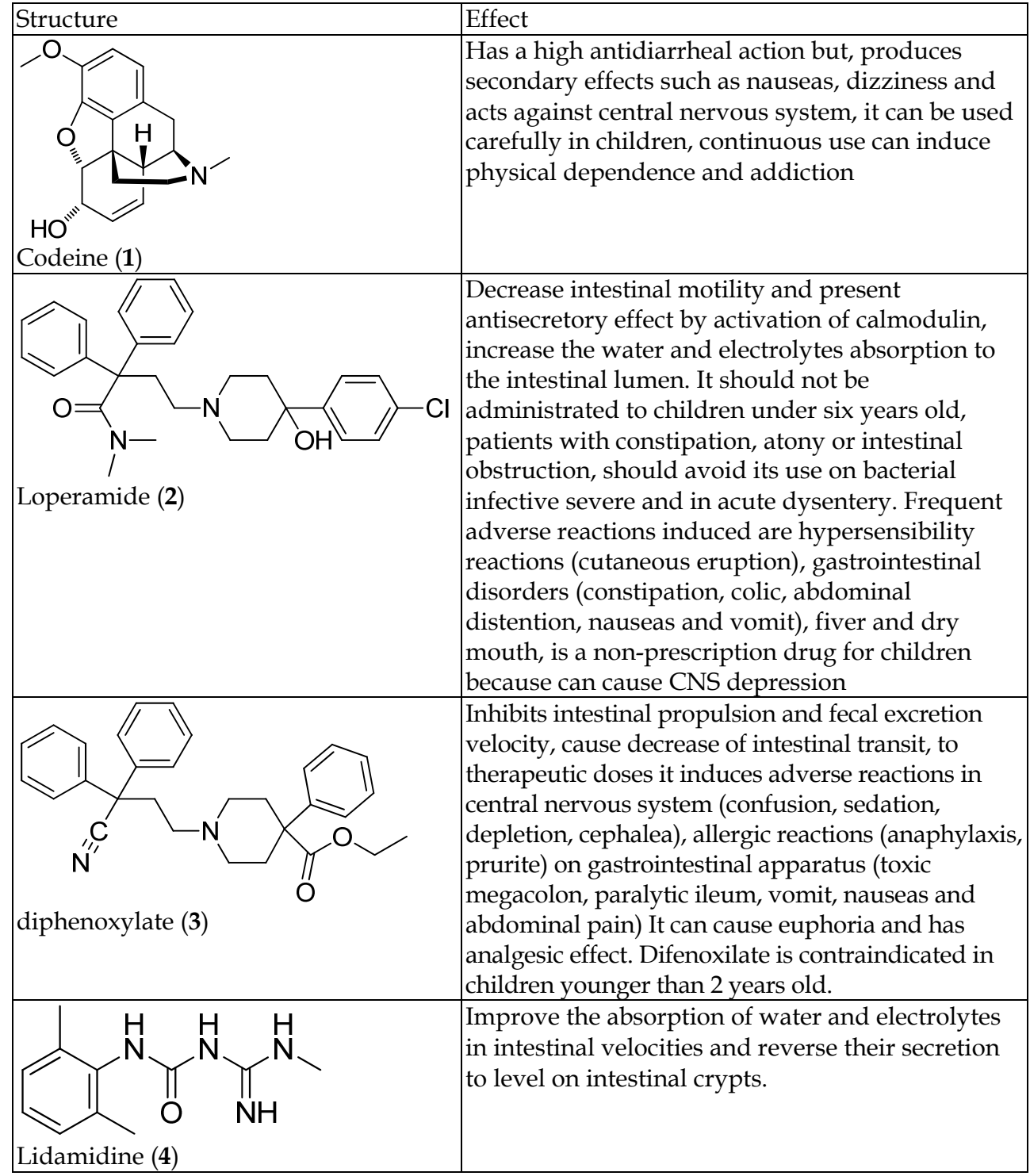




Effect
$\begin{aligned} & \text { Showed antisecretor effect for the inhibition of } \\ & \text { prostaglandins, reduce depositions number and } \\ & \text { reduce abdominal pain, causes adverse reactions } \\ & \text { (dizziness, cephalea, constipation, dark stools, } \\ & \text { ataxia, tremor, encephalopathy, confusion, } \\ & \text { delirium and convulsions). }\end{aligned}$
$\begin{aligned} & \text { Decrease intestinal hipersecretion of water and } \\ & \text { electrolytes to intestinal lumen, inhibits release of } \\ & \text { encephalinse endogenus witch act on opiaceus } \\ & \text { receptors } \gamma \text { decreasing cAMP level (decrease water } \\ & \text { and electrolytes secretion), cause some adverse } \\ & \text { reactions such as hypokalemia, bronchospasm, } \\ & \text { fever, vomit and otitis. }\end{aligned}$
$\begin{aligned} & \text { Stimulates sodium and chloride absorption and } \\ & \text { inhibits chloride secretion by interaction with its } \\ & \text { receptor on enterocyte, causes an alteration of gut } \\ & \text { motility with effect on intestinal transport, it } \\ & \text { causes hypotension }\end{aligned}$

Table 1. Drugs used to treat secretory diarrhea

On the other hand, there are some compounds that showed inhibitory properties on the intestinal secretion Fig 3. such as berberine (8), chlorpromazine (9), nicotinic acid (10), indomethacin (11), somatostatin (12) and ethacrinic acid (13) but they were not developed as antidiarrhoeal drugs (Fedorack and Field, 1987). Thus, the research for new antisecretory agents that should be effective and safe to treat diarrhea is still a necessary goal.<smiles>COc1ccc2cc3[n+](cc2c1OC)CCc1cc2c(cc1-3)OCO2</smiles>

berberine 8<smiles>CN(C)CCCN1c2ccccc2Sc2ccc(Cl)cc21</smiles>

chlorpromazine 9 
<smiles>O=C(O)c1cccnc1</smiles>

nicotinic acid 10<smiles>COc1ccc2c(c1)c(CC(=O)O)c(C)n2C(=O)c1ccc(Cl)cc1</smiles>

Indomethacin $\mathbf{1 1}$

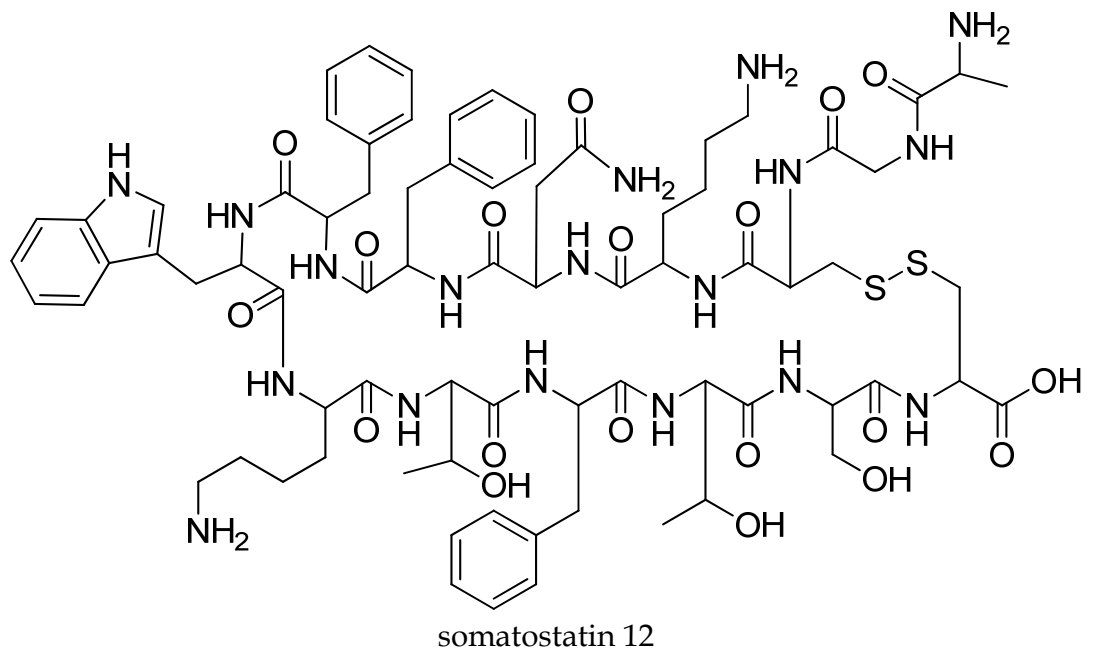<smiles>C=C(CC)C(=O)c1ccc(OCC(=O)O)c(Cl)c1Cl</smiles>

ethacrinic acid $\mathbf{1 3}$

Fig. 3. Compounds with inhibitory properties on the intestinal secretion

\subsubsection{Potential target areas to design therapeutic agents on Vibrio cholerae toxin}

During the last two decades there has been a continuous research of drugs that inhibit the secretory process in the enterocyte to help to the control of diarrhea, but only a few candidates have emerged, and none has found a place in the routine management of secretory diarrhea. Particularly to cholera toxin its mechanism of action revel several potential target areas to design therapeutic agents such as:

a. The inhibition of adenylate cyclase

b. The blockage of the active site of the enzyme located in the A subunit

c. The disruption of the assembly of the holotoxin by interrupting the $\mathrm{A}_{2}$-B interaction

d. The interception of the receptor binding to the bottom of the B pentamer (Guangtao Z., 2009). 
e. Inhibitors of enkephalinase and of the cystic fibrosis transmembrane conductance regulator (Thiagarajah, 2005).

f. Inhibition of transport proteins involved in cAMP activated chloride secretion

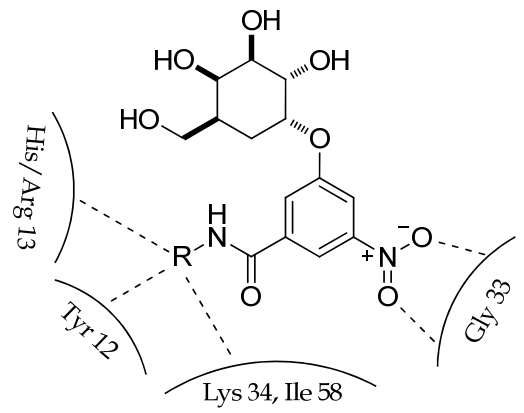

$\mathbf{R}=$<smiles>CCCc1ccccc1</smiles>

14

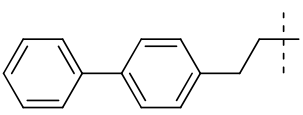

18<smiles>CC(C)(C)CCc1ccccn1</smiles>

22

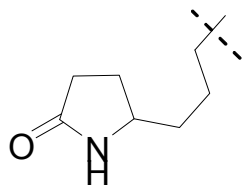

26<smiles>COc1ccc(CC[Te](C)(C)C)cc1</smiles>

15<smiles>COc1ccc(CC[Te](C)(C)C)cc1OC</smiles>

16<smiles>CCCCN1CCOCC1</smiles>

17<smiles>CC(C)(C)CCc1c[nH]c2ccccc12</smiles>

21

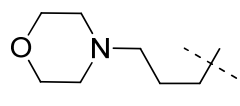

23

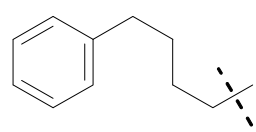

27
24

25<smiles>CC(C)(C)CCc1ccccc1</smiles>

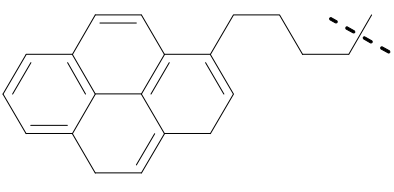

28

Fig. 4. Synergism of structure-based drug design with combinatorial chemistry for the design of receptor antagonist of cholera toxin http://www.bmsc.washington.edu/WimHol/figures/figs2/WimFigs2.html 


\subsection{Medicinal plants as a source of antidiarrheal compounds}

Diarrheal diseases are a health problem because affect a large number of the population mainly children and elderly. In México the use of medicinal plants to treat gastrointestinal disorders including diarrhea occupied the first place, there are few pharmacological and chemical studies which support their use. Approximately $80 \%$ of the world's population uses medicinal plants to treat immediately health problems, is clear the importance of multidisciplinary research of our natural sources. The study of medicinal plants with the propose to provide pharmacological evidence that may explain its therapeutic use

There are some in vitro models such as isolated ileum of guinea pig, isolated jejune of rabbit, ileum and duodenum isolated of rat or rabbit and in vivo reduction of intestinal motility using charcoal meal, Castor oil, $\mathrm{PGE}_{2}, \mathrm{MgSO}_{4}$ induced diarrhea, and Enteropooling models. Antispasmodic activity has been demonstrate for some flavonoids such as quercetin, quercitrin, genistein, sakuranetin, rutin and bisabolol; terpenoids such as himachalol, coleonol, $\beta$-damascenone, $\varepsilon$-fitol, capsidiol, $\beta$-eudemol, hinesol, huatriwaico acid, camaldulin and tymol; essential oils such as, 1,8-cineol, eugeol, timol, carvacrol, estragolanetol, $\alpha$ y $\beta$ pinenes, nonanal, and linalool; alkaloids such as himbacine, protopine, coptisine, cantleyine, mitraginine, vertine, retuline, cavidine and metuenine (Astudillo et al., 2009).

There are a great number of natural remedies for diarrhea control, historically Papaver somniferum preparations are efficient and powerful against diarrhea, as the derivative codeine, alkaloids are ones of major substances explored form natural products and they give to pharmaceutical industry a big number of patents, another class of compound explored therapeutically are flavonoids and has been used as complement in treatment of cancer, heart diseases, venous insufficiency, venous ulcers, hemorrhoids and diarrhea. (Martindale 2009)

\subsubsection{Antisecretory compounds isolated from medicinal plants}

Some studies have been performed in order to find antisecretory compounds from several plants used in traditional medicine to treat several kinds of diarrheas. In this sense the extracts from Croton urucurana, C. lechleri, Berberis aristata and Guazuma ulmifolia were studied against intestinal secretion caused by $V$. cholera toxin, in the cases of C. lechleri, B. aristata and G. ulmifolia the isolated compounds were oligomeric proantocyanidins and berberine, respectively. From C. urucurana saponins, steroids, alkaloids, antocianidins and catechins have been isolated. Prontocianidins and catechins probably can be associated with their antisecretory activity.

Steviol (29) and dihydroisosteviol (30) can inhibit cAMP-activated chloride secretion in human's intestine cells by targeting CFTR (Pariwat 2008). Penta-m-digalloyl-glucose (PDG) (31) isolated of Chinese gallnuts showed efficacy in reducing enterotoxin-induced intestinal fluid secretion in mice (Wongsamitkul et al., 2010)

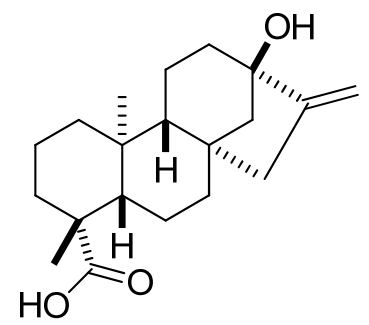

Steviol 29



dihydroisosteviol 30 
Crofelemer (32) is a proanthocyanidin oligomer obtained from Croton lechleri (dragon's blood), the sap has been used to treat diarrheas including dysentery and cholera, pharmacological studies have shown that it reduces fluid secretion in cell culture and mouse models (Gabriel et al., 1999), it has been reported that the antisecretory mechanism of action of crofelemer involves dual inhibition of The cystic fibrosis transmembrane regulator conductance (CFTR), a cAMP stimulated $\mathrm{Cl}$ - channel, and calcium-activated $\mathrm{Cl}^{-}$ channels (CaCC) at the luminal membrane of enterocytes ( preliminary studies showed that crofelemer (32) may reduce watery stool output in patients with infectious diarrhea such as cholera. But it needs further Phase 3 clinical trials are still necessaries (Crutchley et al., 2010).<smiles>O=C(OCC1OC(OC(=O)c2cc(O)c(O)c(OC(=O)c3cc(O)c(O)c(O)c3)c2)C(OC(=O)c2cc(O)c(O)c(OC(=O)c3cc(O)c(O)c(O)c3)c2)C(OC(=O)c2cc(O)c(O)c(OC(=O)c3cc(O)c(O)c(O)c3)c2)C1OC(=O)c1cc(O)c(O)c(OC(=O)c2cc(O)c(O)c(O)c2)c1)c1cc(O)c(O)c(O)c1</smiles>

Penta-m-digalloyl-glucose (PDG) (31)

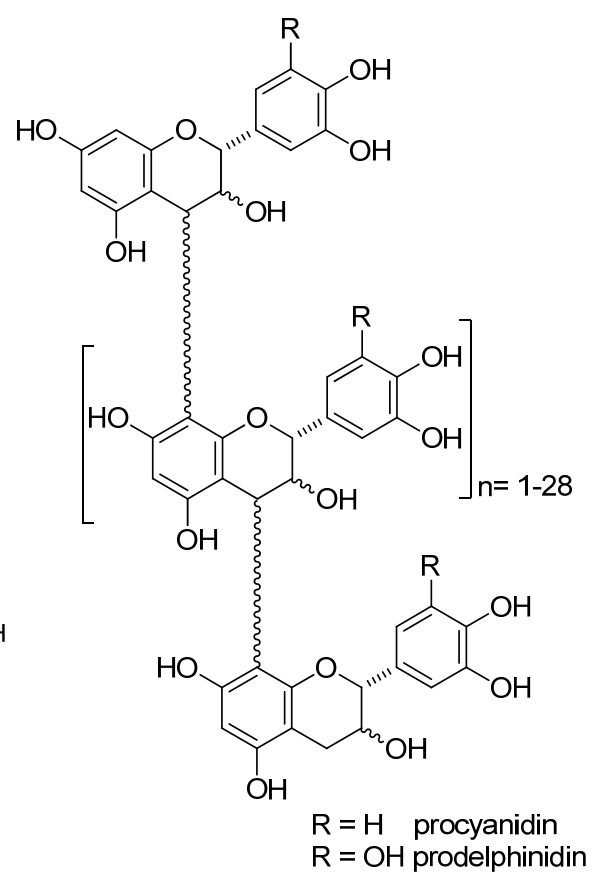

Crofelemer (32)

We continue with the research of compounds with antisecretory activity useful to treat diarrhea. Medicinal plants used in Mexican traditional medicine to treat gastrointestinal disorders could be a source of compounds with therapeutic utility. In México, the use of medicinal plants to treat gastrointestinal disorders such as diarrhea and dysentery is widespread (Aguilar et al., 1994). However most of these plants have not been investigated from a pharmacological point of view to demonstrate their antisecretory properties, which could lead to support their use as antidiarrheal and anti-dysenteric drug in traditional medicine. We screened aqueous and methanol extracts from 26 Mexican medicinal plants to assess their antisecretory activity using the cholera toxin-induced intestinal secretion in rat jejunal loops model. None of this species or their isolated compounds has been previously evaluated as antisecretory agents (Velázquez et al., 2006). 


\subsubsection{Material and methods}

\subsubsection{Plant materials}

The plants used in that study were collected from different regions in Mexico: Mexico City, States of Hidalgo, Mexico, Sinaloa, Guanajuato and Yucatan, all of them were selected according to their use in Mexican traditional medicine to treat gastrointestinal disorders. Voucher herbarium specimens were deposited in Herbarium IMSSM of Instituto Mexicano del Seguro Social and were authenticated by MS Abigail Aguilar.

\subsubsection{Preparation of crude extracts}

The air-dried plant material $(20 \mathrm{~g})$ was extracted by maceration with $300 \mathrm{~mL}$ of $\mathrm{MeOH}$ for 1 week. Then the macerate was filtered and concentrated under reduced pressure at $40^{\circ} \mathrm{C}$. For aqueous extracts, $20 \mathrm{~g}$ of air-dried plant material were extracted by decoction with $100 \mathrm{~mL}$ of distilled water for $30 \mathrm{~min}$, the solution was filtered and lyophilized.

\subsubsection{Cholera toxin}

Lyophilized powder (1mg) of Cholera toxin (SIGMA) containing approximately 220,000 units/mg of protein was suspended in $1 \mathrm{~mL}$ of sterile water. Aliquots of the toxin solution were dissolved in a $1 x$ PBS ( $\mathrm{NaCl} 8 \mathrm{~g}, \mathrm{KCl} 0.2 \mathrm{~g}, \mathrm{Na} 2 \mathrm{HPO} 4.7 \mathrm{H} 2 \mathrm{O}$ o.115 g, KH2PO4 $0.2 \mathrm{~g} / \mathrm{L}$ ) solution with $1 \%$ bovine serum albumin (SIGMA) to obtain a concentration of $3 \mu \mathrm{g} / \mathrm{mL}$.

\subsubsection{Antisecretory assay}

The antisecretory activity of the extracts was tested using a method described by Torres et al., in 1993. Briefly, male Sprague-Dawley rats (200-250 g) were obtained from the animal house of the IMSS. The experimental protocols were in accordance with the official Mexican norm NOM 0062-ZOO-1999 entitled technical specifications for the production, care and use of laboratory animals (SAGARPA 2001). The antisecretory effect of the extract was studied on intestinal secretion indirectly by measuring the fluid accumulation in the intestine following cholera toxin administration to rats. Two jejuna loops were prepared in the rats and inoculated with $3 \mu \mathrm{g} / \mathrm{mL}$ of cholera toxin dissolved in $1 \times$ PBS with $1 \%$ bovine albumin. Rats ( $n=4$ per group by duplicated) were treated orally with each extract $(300 \mathrm{mg} / \mathrm{Kg}$ in 1 $\mathrm{mL}$ of a $2 \%$ DMSO solution in water). Loperamide $(10 \mathrm{mg} / \mathrm{Kg})$ was used as antidiarrhoeal drug. After $4 \mathrm{~h}$, the animals were sacrificed using ethyl ether. The antisecretory activity of the extracts was measured as the fluid accumulation in the loops and expressed in percentage of inhibition. Values are expressed as mean \pm SEM. Statistical significance was determinate using Mann-Whitney U-test. Values with $\mathrm{p}<0.05$ were considered significant.

\subsubsection{Results}

We tested 56 aqueous and methanol crude extracts obtained from 26 medicinal plants used in Mexican traditional medicine for the treatment of gastrointestinal disorders. The antisecretory activity was tested using the cholera toxin-induced intestinal secretion in rat jejunal loops model. Only the principal antisecretory activity of the extracts tested is shown in Table 2, the full list is showed in Velázquez et al., 2006.

In traditional medicine since infusions or decoctions are usually taken three times per day when diarrhea occurs, our results can be related with their traditional use because the used dose is approximately one cup of plant tea which is recommended by Mexican people to treat gastrointestinal disorders (Aguilar et al., 1994).We found that both extracts from Chiranthodendron pentadactylon, Hippocratea excelsa and Ocimum basilicum were the most 
active with inhibition values ranging from 68.0 to $87.6 \%$ at $300 \mathrm{mg} / \mathrm{kg}$. Methanol extract of Geranium mexicanum (aerial parts) and the aqueous extract of Bocconia frutescens were active too with inhibition values of 93.4 and $86.0 \%$, respectively. On the other hand, the methanol extract of Chenopodium ambrosioides green variety (aerial parts), Lygodium venustum, Punica granatum and Ruta chalepensis, the aqueous extracts of Aloysia triphylla, Chenopodium ambrosioides green variety (aerial parts), Dorstenia contrajerva and Schinus molle shown inhibitory activity with values ranging from 43.4 to $79.5 \%$. The $87 \%$ of the extracts tested showed inhibitory activity of the intestinal secretion; only seven extracts did not show any antisecretory activity. In general, among the researched extracts, the methanol extracts exhibited the highest antisecretory activity.

\begin{tabular}{|l|l|l|l|l|l|}
\hline Family & Plant specie & $\begin{array}{l}\text { Part } \\
\text { used }\end{array}$ & $\begin{array}{l}\text { Voucher } \\
\text { number }\end{array}$ & Extract & $\%$ Inhibition \\
\hline Verbenaceae & Aloysia triphylla (L'Hér) Britton & AP & 126110 & $\begin{array}{l}\text { Methanol } \\
\text { Aqueous }\end{array}$ & $\begin{array}{l}7.8 \pm 4.7 \\
80.4 \pm 22.8\end{array}$ \\
\hline Papaveraceae & Bocconia frutescensL. & AP & 12618 & $\begin{array}{l}\text { Methanol } \\
\text { Aqueous }\end{array}$ & $\begin{array}{l}24.1 \pm 15.4 \\
86.0 \pm 9.8\end{array}$ \\
\hline Chenopodiaceae & $\begin{array}{l}\text { Chenopodium ambrosioides L., } \\
\text { green variety }\end{array}$ & AP & 14402 & $\begin{array}{l}\text { Methanol } \\
\text { Aqueous }\end{array}$ & $\begin{array}{l}43.4 \pm 6.5 \\
48.7\end{array}$ \\
\hline Sterculiaceae & $\begin{array}{l}\text { Chiranthodendron pentadactylon } \\
\text { Larreat }\end{array}$ & F & 14104 & $\begin{array}{l}\text { Methanol } \\
\text { Aqueous }\end{array}$ & $\begin{array}{l}87.6 \pm 15.3 \\
84.8 \pm 17.4\end{array}$ \\
\hline Moraceae & Dorstenia contrajerva L. & AP & 14406 & $\begin{array}{l}\text { Methanol } \\
\text { Aqueous }\end{array}$ & $\begin{array}{l}24.4 \pm 16.4 \\
44.8 \pm 5.9\end{array}$ \\
\hline Geraniaceae & Geranium mexicanum H. B. \& K. & AP & 14405 & $\begin{array}{l}\text { Methanol } \\
\text { Aqueous }\end{array}$ & $\begin{array}{l}93.4 \pm 6.7 \\
42.1 \pm 15.2\end{array}$ \\
\hline Hippocrateaceae & Hippocratea excels H. B. \& K. & R & 14394 & $\begin{array}{l}\text { Methanol } \\
\text { Aqueous }\end{array}$ & $\begin{array}{l}80.3 \pm 21.3 \\
75.0 \pm 24.9\end{array}$ \\
\hline Schizaeaceae & Lygodium venustum Sw. & AP & 1270 & $\begin{array}{l}\text { Methanol } \\
\text { Aqueous }\end{array}$ & $\begin{array}{l}51.6 \pm 15.6 \\
0\end{array}$ \\
\hline Labiatae & Ocimum basilicum L. & AP & 14393 & $\begin{array}{l}\text { Methanol } \\
\text { Aqueous }\end{array}$ & $\begin{array}{l}68.7 \pm 9.7 \\
68.0 \pm 20.8\end{array}$ \\
\hline Punicaceae & Punica granatum L. & EF & 14403 & $\begin{array}{l}\text { Methanol } \\
\text { Aqueous }\end{array}$ & $\begin{array}{l}55.9 \pm 3.6 \\
19.1 \pm 6.9\end{array}$ \\
\hline Rutaceae & Ruta chalepensis L. & AP & 14400 & $\begin{array}{l}\text { Methanol } \\
\text { Aqueous }\end{array}$ & $\begin{array}{l}73.7 \pm .01 \\
23.6 \pm 9.27\end{array}$ \\
\hline Anacardiaceae & Schinus molle L. & AP & 14408 & $\begin{array}{l}\text { Methanol } \\
\text { Aqueous }\end{array}$ & $\begin{array}{l}0.5 \pm 17.7 \\
79.5\end{array}$ \\
\hline
\end{tabular}

Table 2. Antisecretory activity of methanol and aqueous extracts of Mexican medicinal plants on intestinal secretion response to cholera toxin, AP: aerial parts, EF: fruit exocarpus, F: flowers, R: roots.

\subsection{Antisecretory study of Chiranthodendron penthadactylon}

We selected Chiranthodendron pentadactylon Larreat (Sterculiaceae) to perform bio-guided assay fractionation. C. pentadactylon know in Mexico as "flor de manita"has been used in Mexican traditional medicine since Aztecs ancient times to treat heart illness, epilepsy, 
diarrhea and dysentery (Linares et al., 1988, Argueta et al., 1994). This study lend to the isolation of some compounds with in vivo antisecretory activity (Velázquez et al., 2009).

\subsubsection{Isolation of active compounds}

The flowers of $C$. pentadactylon were ground and extracted by maceration at room temperature with methanol, the extract was suspended in $10 \% \mathrm{MeOH}$-water and successively partitioned with $\mathrm{CH}_{2} \mathrm{Cl}_{2}$ and EtOAc, the aqueous residual layer was lyophilized. The fractions were tested for antisecretory activity at doses of $50 \mathrm{mg} / \mathrm{Kg}$. The most active fraction was AcOEt with $88.2 \%$ of Inhibition. In order to isolate the active compounds, it was subjected to column chromatogaphy on Sephadex (Pharmacie) using $\mathrm{CHCl}_{3}$ in $\mathrm{EtOH}, \mathrm{MeOH}$ and Water to give eight secondary fractions, further chromatography lend to the isolation of tiliroside (33), astragalin (34), isoquercitrin (35), (+) catechin (36), and (-) epicatechin (37). All the isolated compounds were identified by comparison of spectroscopic data $\left({ }^{1} \mathrm{H}\right.$ and ${ }^{13} \mathrm{C}$ NMR, UV, IR, $[\alpha]$, and TLC and HPLC with authentic samples available in our laboratory (Kuroyanagui et al., 1978; Lee et al., 1992; Lui et al., 1999; Calzada et al., 2007).

\subsubsection{Antisecretory activity of isolated compounds}

Antisecretory activity of the isolated compounds from the AcOEt fraction was tested on cholera toxin-induced intestinal secretion in rat jejunal loops model (table 3). Among the isolated compounds (-) epicatechin (37) showed the best antisecretory activity on the intestinal secretion with an $\mathrm{ID}_{50}$ of $8.3 \mu \mathrm{M} / \mathrm{mL}$, its antisecretory activity was like of loperamide (2) ( $\left.\mathrm{ID}_{50} 6.1 \mu \mathrm{M} / \mathrm{mL}\right)$, isoquercitrin (35) and (+)-catechin (36) showed moderate and weak antisecretory activity, respectively. Tiliroside (33) and astragalin (34) were inactive at doses tested table 3. Flavonoids such as flavan-3-ols and flavonol glycosides have been considered as the active principles of many antidiarrheal plants. Isoquercitrin isolated from Psidium guajava showed spasmolytic effect on guinea pig ileum (Morales et al., 1994). Tiliroside (33) and (-)-epicatechin (37) obtained from Helianthemum glomeratum and Rubus coriifolius, respectively, showed antiprotozoal activity against Entamoeba histolytica and Giardia lamblia (Alanis et al., 2003; Barbosa et al., 2007). Data obtained in this investigation suggest that (-)-epicatechine (37), isoquercitrin (35) and tiliroside (33) may play an important role in antidiarrheal of $C$. penthadactylon in Mexican traditional medicine. Also, our results are in agreement and could explain the result previously obtained by Hör et al., 1995, with antisecretory oligomeric proantocianidins from Guazuma ulmifolia which monomeric unit are $(+)$-catechin (36) and (-)-epicatechin (37). The antiprotozoal activity together with the antisecretory activity is evidences that support the use of these plants to treat diarrhea in Mexican traditional medicine.

Further studies are carried on in order to determinate the action mechanism of active compounds against intestinal secretion caused by Vibrio cholerae toxin (non publicated results), Additionally we are studying some medicinal plants used to treat gastrointestinal disorders in Mexican traditional medicine from Hidalgo, using intestinal propulsion (charcoal meal), castor oil induced diarrhea and castor oil induced intestinal fluid accumulation models in vivo. 
<smiles>O=C(/C=C/c1ccc(O)cc1)O[C@H]1O[C@H](OC2C(=O)c3c(O)cc(O)cc3CC2c2ccc(O)cc2)[C@H](O)[C@H](O)[C@@H]1O</smiles>

tiliroside 33<smiles>O=c1c(O[C@@H]2O[C@H](CO)[C@@H](O)[C@H](O)[C@H]2O)c(-c2ccc(O)c(O)c2)oc2cc(O)cc(O)c12</smiles>

Isoquercitrin (35)<smiles>O=c1c(OC2O[C@H](CO)[C@@H](O)[C@H](O)[C@H]2O)c(-c2ccc(O)cc2)oc2cc(O)cc(O)c12</smiles>

astragalin 34<smiles>Oc1cc(O)c2c(c1)O[C@H](c1ccc(O)c(O)c1)[C@H](O)C2</smiles>

(+)-catechin (36)<smiles>Oc1cc(O)c2c(c1)O[C@H](c1ccc(O)c(O)c1)[C@H](O)C2</smiles><smiles>CN(C)C(=O)C(CCN1CCC(O)(c2ccc(Cl)cc2)CC1)(c1ccccc1)c1ccccc1</smiles>

(-) epicatechin (37)

loperamide (2) 


\begin{tabular}{|l|c|c|c|}
\hline Compound & $\begin{array}{c}\text { Doses } \\
(\mathrm{mg} / \mathrm{Kg})\end{array}$ & $\begin{array}{c}\% \text { of } \\
\text { Inhibition }\end{array}$ & $\begin{array}{c}\mathrm{ID}_{50} \\
(\mu \mathrm{M} / \mathrm{Kg})\end{array}$ \\
\hline MeOH extract & 300 & $87.1 \pm 14.5$ & - \\
\hline EtOAc fraction & 50 & $88.2 \pm 9.5$ & - \\
\hline Tiliroside (33) & 10 & - & Inactive \\
\hline Astragalin (34) & 10 & - & Inactive \\
\hline Isoquercitrin (35) & 10 & - & 19.2 \\
\hline (+)-catechin (36) & 10 & - & 51.7 \\
\hline (-)-epicatechin (37) & 10 & - & 8.3 \\
\hline Loperamide (2) & 10 & - & 6.1 \\
\hline
\end{tabular}

Table 3. Antisecretory activity of $\mathrm{MeOH}$ extract, EtOAc fraction and isolated compounds from Chiranthodendron pentadactylon

\section{Conclusion}

Some of the medicinal plants tested showed antidiarrheal activity in the model used. Both extracts of Annona cherimola, Chiranthodendron pentadactylon, Hippocratea excelsa, Ocimum basilicum, Geranium mexicanum (aerial parts), methanol extract of Ruta chalepensis, Lygodium venustum, Punica granatum, and the aqueous extract of Bocconia frutescens, Aloysia triphylla, Dorstenia contrajerva and Schinus molle showed better antisecretory activity than loperamide. The active extracts found in this study will be an option to develop novel phytodrugs useful to treat fluid loss in diarrhea. These results allows to propose these species as a potential sources of antisecretory compounds and should be therefore subjected to further bioassayguided phytochemical studies to obtain their active principles, the antisecretory compounds isolated from medicinal plants combined with ORS might be useful in decreasing the mortality caused by dehydration. The properties previously described of (-)-epicatechin suggest that it may be a leading compounds in the development of novel antidiarrheal agents. The results obtained give some scientific support to the use of some medicinal plants tested for the treatment of gastrointestinal disorders such as diarrhea.

\section{Acknowledgment}

MS Abigail Aguilar, IMSS herbarium, for authentication of plant material and MS Carlos Carrillo. This study was supported by CONACyT (grant: 3800-M); IMSS-FOFOI (FP-200105) and PROMEP (PROMEP/103.5/10/7313).

\section{References}

Aguilar A., Camacho, R., Chino S., Jáquez P., Lopez E. (1994). Herbario medicinal del Instituto Mexicano del Seguro Social. IMSS. P 43

Alanis A., Calzada F., Cedillo-Rivera R., Meckes M.(2003). Antiprotozoal activity of the constituents of Rubuscoriifolius.Phytotherapy Research, 17, 681-682

Amstrong D., Cohen J. (1999). Infectious diseases, vol 2. Mosby, Spain, pp35: 35.1-35.70

Argueta A., Cano L., Rodarte M (1994). Atlas de las plantas de la medicina tradicional mexicana. Vols I-III. Instituto Nacional Indigenista. Mexico. Pp 644-645 
Astudillo A., Mata R., Navarrete A. (2009). El reino vegetal, fuente de agentes antiespasmodicos gastrointestinales y antidiarreicos. Rev Latinoamer. Quím., 37, 1, 744

Barbosa E., Calzada F., Campos R. (2007). In vivo antigiardial activity of three flavonoids isolated of some medicinal plants used in Mexican traditional medicine for the treatment of diarrhea. J of ethnoph 109. 552-554

Calzada F., Alanis AD. (2007). Additional antiprotozoal flavonol glycosides of the aerial parts of Helianthemum glomeratum. Phytotherapy research, 21, 78-80

Capasso F., Grandolini G., Izzo A., (2006) FitoterapiaImpiegoRazionaledlleDrogheVegetali (TirthEdition) Springer, ISBN 10: 88-470-0302-4, Printed in Italia.

Casburn-Jones C., Farthing, M. (2004). Management of infectious diarrhoea.Gut, 5.296-305.

Crutchley R., Miller J., Garey K. (2010).New drug developments: Crofelemer, a Novel Agent for treatment of secretory diarrhea. Ann Pharmacother. 44, 878-884

Farthing M. (2002). Novel targets for the control of secretory diarrhea Gut 50. Iii15-iii18

Fedorack R., Field M.(1987). Anthidiarrheal therapy prospects for new agents. Digestive disease and sciences 32. 195-205.

Filbin, M., Lee, L., Shaffer B., Caughey A. (2004).Blueprints Pathophysiology: Pulmonary, gastrointestinal and rheumatology. Blakwell publishing, ISBN: 1-4051-0351-5, p 66

Guangtao, Z. ( 2009). Desing and in silico screening of inhibitors of the cholera toxin. Expert Opinion on Drug Discovery.InformaHealthcarpublisher, Vol 4, No. 9, pp 923-938

Kopic S., Geibel J. (2010). Toxin mediated diarrhea nin the 21st century: The pathophysiology of intestinal ion transport in the course of ETEC, $V$. cholerae and Rotavirus infection. Toxins 2, 2132-2157 ISSN 2072-6651 (www.mdpi.com/journal/toxins)

Kuroyanagui, M., Fukuoka, M., Yoshihira, K. (1978). Confirmation of the structure of tiliroside, an acylatedkaemperol glycoside by 13C,-nuclear magnetic resonance. Chemical \& Pharmaceutical Bull, 26, 3593-3596

Lee, W., Maremoto, S., Nonaka G., Noshioka, I. (1992).Flavan-3-ol gallates and proanthocyanidins from Pithecellebiumlobatum.Phytochemistry, 31, 2117-2120

Liu, H., Orjalata, J., Sticher, O. (1999). Acylatedflavonol glycosides from the leaves of Stenochlaenapalustris, Journal of Natural Products 62, 70-75

Linares E., Flores B., Bye R. (1988). Selección de plantas medicinales de México. Limusa. México, p 44

Marion K., Scarlett H., Webber K. (2010) Clinical Drug Therapy for Canadian Practice. 2nd edition, Lippincott Williams \& Wilkins Editor. ISBN 1605475173, chapter 16, section 9, p 991

Martindale (2009)The Complete Drug Reference (Thirty-sixth edition) ,Pharmaceutical Press, ISBN 978085369840 1, Printed in China by Everbest Printing Co. Ltd

Morales MA., Tortoriello J., Meckes M. ( 1994). Calcium antagonist effect of quercetin and its relation with the spasmolytic properties of Psidium guajava. Archives Medical Research 25, 17-21.

Sixma T. K., Pronk S. E., Kalk K. H., Wartna E. S., Zanten B A., Witholt B., Hoi W. G. (1991) Nature. 351, 371-377.

Navaneethan U., Giannella R. (2010). Diarrhea Diagnostic and therapeutic advances. Chapter 1 in Guandalini S. and Vaziri H. editors, e-ISBN 978-1-60761-183-7. Springer science+Busines media p 1-16 
SAGARPA (Secretaria de agriculturaganaderíadesarrollorural pesca y alimentación) 2001. Norma oficialmexicana (NOM-062-ZOO-1999).Especificacionestécnicaspara la producción, cuidado y uso de los animales de laboratorio. Diariooficial, México, pp $16-20,5,6,8-45$.

Spangler, B. (1992).Structure and function of Cholera toxin and the related Escherichia coli Heat-labile enterotoxin.Microbiological rewiews, vol. 56, No. 4, p 622-647.

SS (Secretaría de Salud) 2008. SistemaNacional de VigilanciaEpidemiológica.Epidemiologia 34, semana 4, ISNN: 1405-2636.

Thiagarajah, J. R.,Verkman, A. S. (2005). New Drug Targets for Cholera Toxin.PharmacolSci, Vol. 26, No.4, pp. 172-5

Velázquez C., Calzada F., Torres J., González F., Ceballos G. (2006). Antisecretory activity of plants used to trat gastrointestinal disorders in Mexico. Journal of Ethnopharmacology, 10, 66-70

Velázquez, C., Calzada, F., Esquivel, B., Barbosa, E., Calzada, S. (2009).Antisecretory activity from the flowers of Chiranthodendronpentadactylon and its flavonoids on intestinal fluid accumulation induced by Vibrio cholerae toxin in rats.Journal of Ethnopharmacology, 126, 455-458 


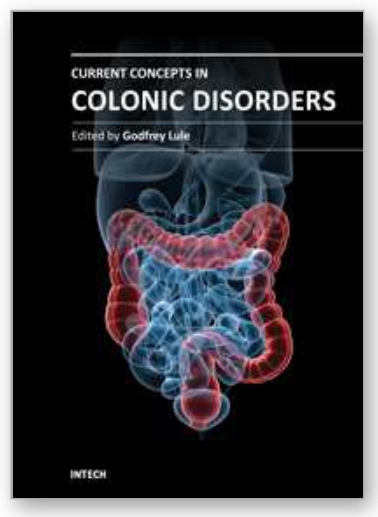

\author{
Current Concepts in Colonic Disorders \\ Edited by Dr. Godfrey Lule
}

ISBN 978-953-307-957-8

Hard cover, 276 pages

Publisher InTech

Published online 05, January, 2012

Published in print edition January, 2012

The 21 st Century has seen a resurgence of research of the gastrointestinal tract, especially since it was established that it plays a central role as an immune system organ and consequentially has a huge impact on causation, impact and transmission of most human ailments. New diseases such as the Acquired Immunodeficiency Syndrome, hepatitis and tumours of the gastrointestinal tract have emerged and they are currently subjects of intensive research and topics of scientific papers published worldwide. Old diseases like diarrhea have become extremely complex to diagnose with new and old pathogens, drugs, tumours and malabsorptive disorders accounting for the confusion. This book has set out algorithms on how to approach such conditions in a systematic way both to reach a diagnosis and to make patient management cheaper and more efficient. "Current Concepts in Colonic Disorders" attempts to put all the new information into proper perspective with emphasis on aetiopathogenesis and providing rational approach to management of various old and new diseases. As the book editor, I have found this first edition extremely interesting and easy to understand. Comments on how to improve the content and manner of presentation for future editions are extremely welcome.

\title{
How to reference
}

In order to correctly reference this scholarly work, feel free to copy and paste the following:

Claudia Velázquez, Fernando Calzada, Mirandeli Bautista and Juan A. Gayosso (2012). Management of Secretory Diarrhea, Current Concepts in Colonic Disorders, Dr. Godfrey Lule (Ed.), ISBN: 978-953-307-957-8, InTech, Available from: http://www.intechopen.com/books/current-concepts-in-colonic-disorders/managementof-secretory-diarrhea

\section{INTECH}

open science | open minds

\section{InTech Europe}

University Campus STeP Ri

Slavka Krautzeka 83/A

51000 Rijeka, Croatia

Phone: +385 (51) 770447

Fax: +385 (51) 686166

www.intechopen.com

\section{InTech China}

Unit 405, Office Block, Hotel Equatorial Shanghai

No.65, Yan An Road (West), Shanghai, 200040, China

中国上海市延安西路65号上海国际贵都大饭店办公楼405单元

Phone: +86-21-62489820

Fax: $+86-21-62489821$ 
(C) 2012 The Author(s). Licensee IntechOpen. This is an open access article distributed under the terms of the Creative Commons Attribution 3.0 License, which permits unrestricted use, distribution, and reproduction in any medium, provided the original work is properly cited. 